\title{
OIL PASS-THROUGH TO DOMESTIC PRICES IN TURKEY: DOES THE CHANGE IN INFLATION REGIME MATTER?
}

\author{
A. NAZIF ÇATIK ${ }^{1}$ \\ MEHMET KARAÇUKA ${ }^{2}$
}

\section{ARTICLE INFO}

JEL classification: C32, E31, E42

Keywords:

- Inflation

- Oil shocks

- Pass-through

-Regime-dependent impulse

responses

- MS-VAR model
ABSTRACT

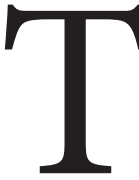

his paper investigates the existence of oil pass through to inflation under different inflation regimes in Turkey. between the oil pass-through effects in the low and high inflation periods we employ Markov Regime Switching Vector Autoregressive (MS-VAR) model as a non-linear estimation framework. The regime-dependent impulse responses do not indicate strong pass through from crude oil prices to inflation in both regimes. However, this channel is working through refined petroleum product prices. The results show that there is a substantial decline in pass-through from refined petroleum prices to inflation as the economy moves from high to low inflation regime. These findings support the hypothesis of Taylor (2000) suggesting that low inflationary environment leads to a low pass-through.
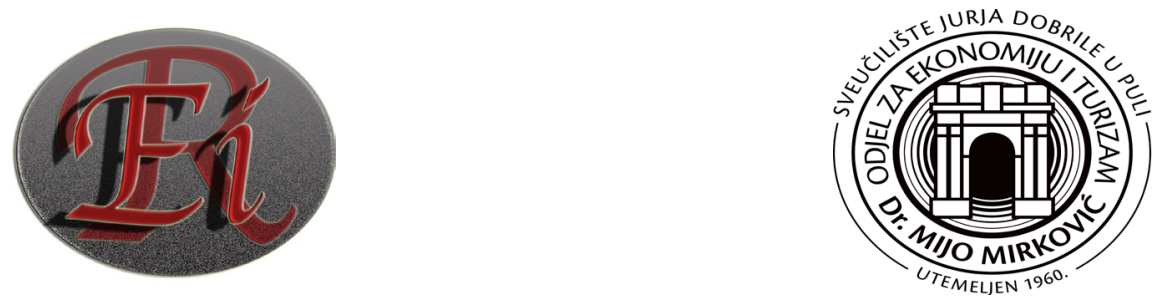

${ }^{1}$ Ege University, Department of Economics, +90 232311 1843, a.nazif.catik@ege.edu.tr, Izmir/Turkey

${ }^{2}$ Ege University,Department of Economics, +90 232311 5298, mehmet.karacuka@ege.edu.tr, Izmir/Turkey 


\section{INTRODUCTION}

The price of oil and overall price level in an economy are usually seen as being connected together. The main reason is that oil products are not used only as final consumer goods but also used as inputs for almost all kind of economic activities, and a price change in oil products assumed to be passing through to the prices of other products via direct and indirect ways. Direct effects are referred to the initial increases in the consumer prices as energy constitutes an important share in final consumption, whereas indirect effects arise as a result of an increase in the producer prices that in turn pass on to the consumer prices.

The coexistence of two consecutive oil shocks and stagflation in the major world economies during the 1970's has attracted a great deal of research interest in order to understand the relationship between oil prices and economic activity. Earlier studies find that there is a strong pass-through effect of oil shocks on inflation. Using the St. Louis type equations augmented with the change in real oil prices covering the 1962-1982 sample period, Gisser and Godwin (1986) finds that crude oil prices has a significant effect on the macroeconomic variables including inflation in the U.S. Burbidge and Harrison (1984) consider seven OECD countries along with the U.S. and estimate a seven-variable VAR model compromising industrial production, crude oil and consumer prices and the other key macroeconomic variables covering the period 1962-1982. Their impulse-response and historical decomposition results suggest that both 1973 and 1979 oil shocks have led to significant inflation in developed economies.

Oil prices remained stable for almost two decades after a decreasing period in the early 1980's with few exceptions. The upcoming years after 2000 witnessed a much more volatile and higher oil prices on average. However studies conducted after 2000s find that strong pass-through effect has declined as other determinants of inflation have been lessened by either structural change or controlled by policy makers in the developed economies. For example, Hooker (2002) finds that oil price pass through effect is negligible after 1980 in USA, estimating a Phillips curve model. LeBlanc and Chinn (2004) also based on Phillips curve framework; find that oil price increases have small effects on inflation in five developed countries. Blanchard and Gali, (2007) based on their VAR analysis dividing the sample as pre 1983 and post 1984 show that the dynamic effects of oil shocks have decreased over time in six developed countries subject to the analysis.

The results obtained from different studies suggest that the effects oil shocks on economic activity and consumer prices vary across the countries, and the investigation periods. Taylor (2000) argues that the pass-through effects are nonlinear, i.e. there is little pass through when the economy experiences a low inflation environment, and vice versa. Chen (2009), using a state space approach to cover time varying effects within a vector error correction (VEC) model, confirms the recent findings that pass-through effects into inflation have been declining, based on data from 19 industrial countries. However, he finds no evidence to support Taylor hypothesis that a lower inflation environment can lower pass- through effects.

In this study we aim to extend the empirical literature on the pass through effects of oil prices on inflation in a developing country perspective. Turkey is an interesting case in some distinguished ways. First, Turkey has moved from high to low inflation regime as a result of the implemented stabilization program following the November 2000-February 2001 crisis, and this led to changes in the estimated parameters in modeling inflation (see, Önder, 2009 
for details). Second, oil constitutes a high share in total energy consumption $(32 \%)^{3}$ in Turkey, and $95 \%$ of oil demand is supplied by imports (EMRA, 2010).

The share of crude petrol constituted around $5 \%$ of total imports in Turkey by 2009 . These features make the Turkish economy not only vulnerable to the world prices of oil, but also to the exchange rates. Another interesting feature of Turkey is that taxes imposed on oil products are the highest in the world and constitute nearly $70 \%$ of prices. Therefore, an increase in the oil prices may also have an indirect disinflationary effect given the increasing tax revenues help government to reduce budget deficit ${ }^{4}$.

Despite the importance of oil in Turkish economy, relatively few studies have analyzed the effects of oil shocks on inflation. Aydoğuş (1993), and Berument and Taşçı (2000) investigate the effects of oil shocks using Input-Output analysis at the sectoral level. They found weaker support for the inflationary effects of oil prices. Along with the sectoral Input-Output analysis Kibritçioğlu and Kibritçioğlu (1999) employ a linear VAR model including inflation, oil prices including the other key macroeconomic variables with a relatively short sample (monthly data from 1986:01 to 1998:03). Their result does not indicate any direct and significant oil pass through. We find only one study Çatık and Önder (2011) investigating the inflationary impacts of oil prices by employing a nonlinear model. In that study, oil price-augmented Phillips curves are estimated with Markov regime-switching models covering the period 1996-2007. The regime-switching regressions reveal the existence of two different regimes characterized as the high- and the low-inflation periods. They find evidence for asymmetric oil pass-through in the high-inflation regime. Their results confirm the Taylor hypothesis suggesting that the pass-through effect of oil prices has declined significantly with the successful implementation of inflation targeting policy.

This main of this paper is to analyze the evolution of the pass-through effect of oil prices for Turkey under possible regime changes. Our study differs from the previous studies in two ways. First, unlike the single-equation Markov regime-switching Phillips curve estimates of Çatık and Önder (2011), we employ a Markov Regime Switching Vector Autoregressive (MS-VAR) model. Regime-dependent impulse responses derived from this model allow us to compare the significance of the difference between the oil pass-through under the high and the low inflationary periods. Finally, we use refined petroleum products index to establish the link between imported oil price changes and the inflation due to the key role of exchange rate movements and also taxes in the formulation of the petroleum products prices.

The rest of the paper is organized as follows. In the following section we introduce our data and methodology. Empirical findings on MS-VAR estimates and regime-dependent impulse response functions are presented in section three. Finally, conclusions are put forward in the last section.

\footnotetext{
${ }^{3}$ The ratio of oil in energy demand was around $45 \%$ until 1996, before natural gas networks started to provide imported gas as an alternative energy resource.

${ }^{4}$ As one referee points out, increasing taxes may also cause an increase in consumption, and may impose no effect in the budget deficit.
} 


\section{Data and Methodology}

\section{A. Data}

In order to analyze inflationary effects of oil prices we construct a six variable VAR system. A similar recursive VAR model is first used by McCarty (1999) to analyze exchange rate passthrough. We use monthly data covering the period 1994:1-2009:10. ${ }^{5}$ Variables in the model are mainly collected from the Central Bank of Republic of Turkey (CBRT) Electronic Data Delivery System and Turkish Statistical Institute (TURKSTAT). The vector of endogenous variables used in the model is given as follows:

$$
Y_{t}^{\prime}=\left[\text { Dlpet }_{t} \text { Dlrpet }_{t} \text { ipgap }_{t} \text { Dler }_{t} \text { Dlwpi }_{t} \text { Dlcpi }_{t}\right]
$$

All variables are in natural log-first difference form and seasonally adjusted except for exchange rate ${ }^{6}$. Dlpet $t$ is the monthly change in the log of imported crude oil prices in US dollars. Dlrpet $t_{t}$, calculated as the change in the log of refined petroleum products price index, is used to consider the dynamics of oil price determination. Using this variable we aim to establish the link between imported oil price changes and the inflation variables, this is not considered by the previous studies on Turkey. Output gap ( ipgap $_{t}$ ) demand shock variable is measured as the gap between actual and potential industrial production. Hodrick and Prescott (1997) filter is used to compute potential output. Dlne $e_{t}$ is the change in exchange rate computed as the monthly average of nominal Turkish lira-to-U.S. dollar exchange.

Dlnwpi $_{t}$ and Dlncpi $i_{t}$ are the inflation variables based on Wholesale Price Index (WPI) and Consumer Price Index (CPI), they are also calculated in terms of month on month change in the natural log price indices. ${ }^{7}$

\section{B. Markov Switching Vector Autoregressive Model}

Nonlinear impulse responses used in this study are derived from MSIH (Markov Switching Intercept Heteroscedasticity) specification of MS-VAR model proposed by Krolzig and Toro (2001) and Krolzig (2006). MSIH (Markov Switching Intercept Heteroscedasticity) specification covers regime-dependent intercepts and variance of the residuals and regime invariant autoregressive coefficients. Regime-dependent impulse responses can analyze the reaction of the variables to Gaussian innovations under different regimes. In addition, the regime-dependent responses also allows us to measure the responses of variables to the

\footnotetext{
${ }^{5}$ Estimation sample is determined by the availability of refined petroleum product price index obtained from TURKSTAT Refined petroleum products index is a subcomponent of wholesale prices and includes the prices of gasolines, kerosene, distillate fuel oils, lpg (liquefied petroleum gas), asphalt, lubricating oils, diesel fuels, and residual fuels.
${ }^{6}$ Unit root properties of the variables are checked with ADF and Phillips Perron tests. All variables are found to be I(0) at least at 5\% significance level. Since those tests ignore implications of structural breaks on the integration levels of the variables, Zivot and Andrews (1992) unit root tests are also applied. This test confirms the stationarity of variables under a structural break. The results of those tests are available upon request from the corresponding author.

${ }^{7}$ Turkish Statistical Institute (TURKSTAT) has stopped the publication of Consumer and Wholesale price indices with 1994 base year in 2005. Therefore 2003 base year series are combined with the earlier series to obtain the price changes after 2005. 
transition from one to another regime.These steps are followed to derive regime-dependent impulse response functions (Krolzig and Toro, 2001 and Krolzig, 2006). ${ }^{8}$ First MS-VAR model is defined by the following equations,

$$
\begin{gathered}
Y_{t}=v\left(s_{t}\right)+A(L) Y_{t-p}+u_{t}, \\
u_{t} \sim \operatorname{NID}\left(0, \Sigma\left(s_{t}\right)\right) .
\end{gathered}
$$

Where $A(L)$ represents a regime invariant polynomial with order lag order $p$. The state variable $s_{t}$ is an unobserved variable determining the state of the regime. $Y_{t}$ is the previously defined vector of endogenous variables. This model assumes that state variable $s_{t}$ follows an ergodic $M$-state first order Markov chain defined by the following transition probabilities:

$$
p_{i j}=\operatorname{Pr}\left[s_{t}=j \mid s_{t-1}=i\right], \quad \sum_{i=1}^{m} p_{i j}=1 \quad i, j=1, \ldots, M
$$

Where $M$ denotes the number of possible regimes and $p_{i j}$ is the probability that event $i$ is followed by event $j$, and a member of the following transition matrix:

$$
P=\left[\begin{array}{cccccc}
p_{11} & p_{21} & . & . & . & p_{M 1} \\
p_{12} & p_{22} & . & . & . & p_{M 2} \\
\cdot & \cdot & . & \cdot & . & \cdot \\
p_{1 M} & p_{2 M} & . & . & . & P_{M M}
\end{array}\right]
$$

The estimation of MS-VAR model is based on maximum likelihood method. based on Expectation Maximization algorithm by Dempster et al. (1977). ${ }^{9}$ In order to derive impulse responses from the estimated MS-VAR model, information about the realization of the state variable $s_{t}$ is collected to the following regime vector $\xi_{t}$,

$$
\xi_{t}=\left[\begin{array}{l}
I\left(s_{t}=1\right) \\
\cdot \\
\cdot \\
I\left(s_{t}=M\right)
\end{array}\right]
$$

\footnotetext{
${ }^{8}$ MS-VAR models are estimated with Krolzig's MS-VAR package written in Ox.

${ }^{9}$ Maximization of likelihood function includes two stages according to EM algorithm. In the first stage initial values of the parameters are determined and then based on the initial values transition probabilities are computed. In the second stage called as maximization, maximum likelihood estimates of parameters are obtained using the previously computed transition probabilities. These stages are repeated until the parameters converge. Filtered and smoothed probabilities computed through the EM algorithm are used to determine classification of the regimes.
} 
Where the indicator variables are defined by the following vector

$$
I\left(s_{t}=m\right)=\left\{\begin{array}{l}
1 \text { if } s_{t}=M \\
0 \text { otherwise. }
\end{array}\right.
$$

for $m=1, \ldots, M$. Using the regime vector $\xi_{t}, \operatorname{MSIH}(M)-\operatorname{VAR}(p)$ representation of the model can be reformulated as follows:

$$
Y_{t}=H \xi_{t}+A(L) Y_{t-p}+u_{t}
$$

Where $H=\left[\begin{array}{l}M \\ \cdot \\ \cdot \\ \cdot \\ 0\end{array}\right]=t_{1} \otimes M$ and $u_{t}$ is vector of error terms and $\mathrm{i}_{j}$ is the $j^{\text {th }}$ column of the identity matrix.

State space representation of MS-VAR model is completed by the following first order Markov chain:

$$
\xi_{t+1}=F \xi_{t}+v_{t}
$$

where $v_{t}$ is the vector of normally distributed error terms and $F$ is transpose of the transition probabilities matrix. Using this information, the expectation of $Y_{t+h}$ is calculated as :

$$
Y_{t+h \mid t}=H \xi_{t+h \mid t}+A Y_{t+h-1 \mid t},
$$

where the conditional expectation of $\xi_{t+h}$,

$$
\xi_{t+h \mid t}=F^{h} \xi_{t}
$$

If variance covariance matrix of $\Sigma_{u}$ does not change with respect to regime, linear impulse responses is calculated using (8) as follows:

$$
\frac{\partial Y_{t+h \mid t}}{\partial u_{j t}}=J A^{h}{ }_{j},
$$


Where $J=\left[\begin{array}{lllll}I_{k} & 0 & . & . & 0\end{array}\right]=l_{1}^{\prime} \times I_{K}$ denotes a matrix with $(K \times K p)$ dimension. If variance covariance matrix of $\Sigma_{u}$ becomes regime-variant, regime-dependent impulse responses based on the responses of the variables to the same shocks under different regimes, is calculated as

$$
\frac{\partial Y_{t+h \mid t}}{\partial \varepsilon_{j t}}=J A^{h} D\left(\xi_{t}\right) l_{j},
$$

Where $D\left(\xi_{t}\right)$ represents the lower triangular matrix computed from Cholesky decomposition of regime-dependent variance covariance matrix of $\sum_{u}\left(\xi_{t}\right)=D\left(\xi_{t}\right) D\left(\xi_{t}\right)^{\prime}$.

\section{Empirical Results}

Before proceeding to impulse response analysis, linearity of the model is checked. For this purpose two regime MS-VAR model, $\operatorname{MSIH}(2)-\operatorname{VAR}(p)$, and its linear counterpart are estimated up to 6 lags and the log-likelihood, Akaike information Criterion (AIC), Schwarz Bayesian Criterion (SBC) and Hannan Quinn Criterion (HQC) values are reported in Table 1. The log likelihood values of the MS-VAR models are higher than that of corresponding linear VAR model. The best fit is obtained when MS-VAR is estimated with 2 lags. When we compare the information criterions of MS-VAR model with the Linear VAR model, the MS-VAR model fit is better than the linear VAR model since it has lower AIC, SBC and HQC values. Along with the information criterion, Likelihood Ratio $(L R)$ linearity tests based on the difference between the log-likelihood of MS-VAR and Linear VAR are also computed. The LR linearity tests reject the null hypothesis of Linear VAR model against the alternative of MSIH specification in all lags hence they also provide a further evidence in favor of nonlinear model.

TABLE 1. Testing the Nonlinearity and Lag Length in MS-VAR Model

\begin{tabular}{|c|c|c|c|c|c|c|}
\hline \multirow[t]{2}{*}{ No. of Lags } & \multicolumn{2}{|c|}{1} & \multicolumn{2}{|c|}{2} & \multicolumn{2}{|c|}{3} \\
\hline & MS-VAR & Linear VAR & MS-VAR & Linear VAR & MS-VAR & Linear VAR \\
\hline Log-likelihood & 2564.166 & 2415.281 & 2760.640 & 2582.699 & 2644.188 & 2531.507 \\
\hline AIC criterion & -26.161 & -24.892 & -26.335 & -24.874 & -25.864 & -24.979 \\
\hline HQ criterion & -25.266 & -24.186 & -25.521 & -24.454 & -24.475 & -23.791 \\
\hline SC criterion & -23.960 & -23.811 & -24.583 & -23.176 & -22.434 & -22.046 \\
\hline LR linearity test & 297.7694 & $(0.00)$ & 355.8838 & $(0.00)$ & 225.3628 & $(0.00)$ \\
\hline \multirow[t]{2}{*}{ No. of Lags } & \multicolumn{2}{|c|}{4} & \multicolumn{2}{|c|}{5} & \multicolumn{2}{|c|}{6} \\
\hline & MS-VAR & Linear VAR & MS-VAR & Linear VAR & MS-VAR & Linear VAR \\
\hline Log-likelihood & 2628.057 & 2489.539 & 2599.687 & 2449.567 & 2717.008 & 2564.509 \\
\hline AIC criterion & -26.075 & -24.916 & -26.155 & -24.759 & -26.254 & -24.947 \\
\hline HQ criterion & -24.935 & -23.978 & -24.445 & -23.070 & -24.614 & -23.509 \\
\hline SC criterion & -23.262 & -22.600 & -21.669 & -20.591 & -22.206 & -21.397 \\
\hline LR linearity test & 277.0364 & $(0.00)$ & 300.2399 & $(0.00)$ & 304.9982 & $(0.00)$ \\
\hline
\end{tabular}

SOURCE: Author

Notes: The probability of Likelihood Ratio (LR) linearity test are given in parentheses. The LR linearity test tests the null hypothesis that the true model is a linear against the alternative of MSIH and is distributed as $\chi^{2}(q)$ where $q$ is equal to the number of restrictions under which the two models are identical. 
The Maximum likelihood estimation of the selected MSIH(2)- VAR(2) model is reported in Table A1. The diagnostic statistics, autocorrelation functions (ACF) and the partial autocorrelation functions (PACF) and the spectral density suggest that MS-VAR residuals are not significantly autocorrelated. Quantile-Quantile $(Q Q)$ plots also indicates roughly normality of the residuals and hence the model is correctly specified (see Figure A2 in Appendix).

SMOOTHED AND FILTERED PROBABILITIES OF MS-VAR MODEL

\section{FIGURE 1}
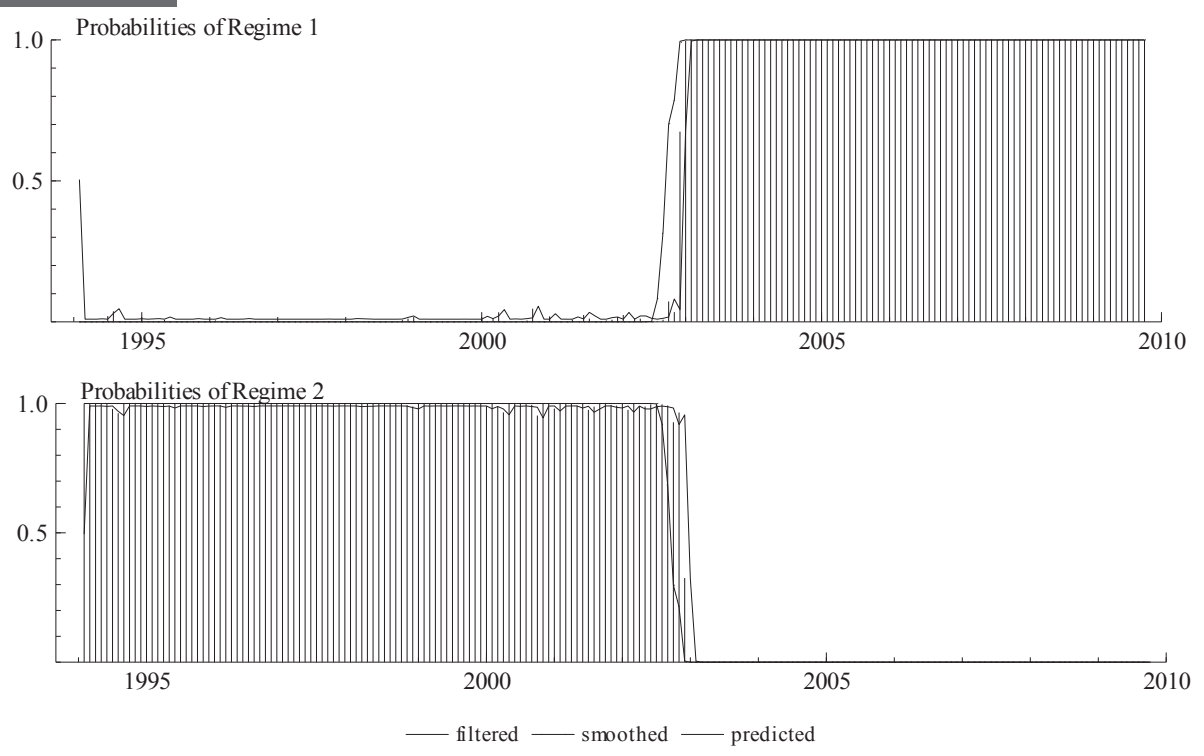

SOURCE: Author

Smoothed and filtered probabilities illustrate the regime classifications computed through the EM algorithm (see Figure 1). As it seen, regimes are properly identified by high transition probabilities. Regime 1 covering the period 2002:10 - 2009:10 can be identified as the low inflation regime with $9.69 \%$ average annual CPI inflation. During that time inflation targeting strategy with floating exchange rate is implemented within the maintaining price stability objective of the Central Bank of Republic of Turkey. As a result of the inflation targeting policy, inflation was successfully decreased to single-digit level by the end of 2004. Regime 2 covering the period up to 2002:10 can be characterized as the high inflation regime, with average annual inflation rate of 53.6\%. During that period Turkish economy experienced 1994 and 2001 crises as a result of the banking sector fragility and accumulating current account deficits (Akyürek, 2006). 
TABLE 2. Transition Probabilities and Regime Properties

\begin{tabular}{lccc}
\hline & Transition Probabilities & & \\
Regime 1 & Regime 2 & \\
Regime 1 & 0.977 & 0.023 & \\
Regime 2 & 0.033 & 0.967 & \\
& Regime Properties & & Duration \\
& Number of Obs. & Prob. & 44.248 \\
Regime 1 & 84.9 & 0.449 & 30.488 \\
Regime 2 & 104.1 & 0.551 & \\
\hline
\end{tabular}

SOURCE: Author

The properties and transition probabilities of the high and low inflation regimes are reported in Table 2. Regime 2, high inflation regime, has more number of observations with the longest duration and highest probability. Regime 1 has a shorter duration, with 30 months and contains $45 \%$ of the total number of observations. Diagonals of the transition matrix ( $p_{11}$ and $p_{22}$ ) illustrating the probabilities of the system remaining in the current regime are found to be more than $90 \%$ for both regimes. Therefore regimes are persistent, when the system is exposed to an exogenous shock, it will most likely move towards the same regime.

Having estimated regime switching model, we compute regime-dependent impulseresponse functions based on equation (12). To compare cumulative impulse response figures between the low and high inflation regimes in terms of magnitude pass-through coefficients are calculated following Rabanal and Schwartz (2001). Accordingly, pass-through coefficients are computed as the ratio of the $j$-month cumulative response of the each variables to the j-month cumulative response of the variables own shock. ${ }^{10}$

CUMULATIVE RESPONSES TO ORTHOGONAL SHOCK TO Dlpet $t_{t}$

\section{FIGURE 2}

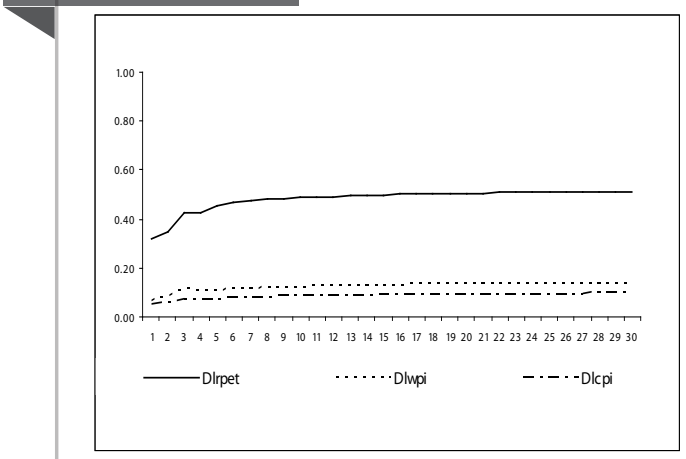

Regime 2 (High Inflation Regime)

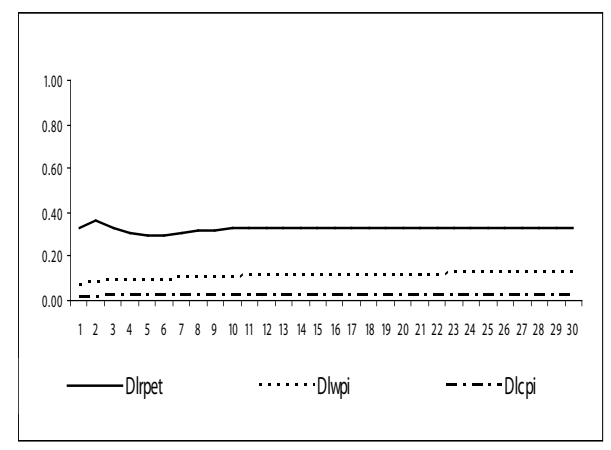

Regime 1 (Low Inflation Regime)

SOURCE: Author

Figure 2 reports cumulative responses of refined petroleum, wholesale and consumer prices to imported oil price shocks. The responses of inflation variables to imported crude oil price shocks are found to be very limited as far as both regimes are concerned. This may suggest

${ }^{10}$ The pass-through coefficient is calculated as $P T_{t, t+j}=P t, t+j / E_{t, t+j}$ where $P_{t+j}$ is the cumulative change in the price level and $E_{t+j}$ is the cumulative change in the exchange rate between months $t$ and $t+j$. 
the insignificance of direct inflationary impact of crude oil prices. However, the pass through from oil prices to refined petroleum prices is found to be higher in Regime 2.

In the high inflation regime $13.7 \%$ of changes in imported crude oil prices are passed to wholesale prices within six months, this figure shows a slightly declining trend in the low inflation regime with $12.1 \%$. However, the difference between high and low inflation periods are more pronounced when the pass-through to consumer prices are considered. Cumulative effect of pass-through to CPI has decreased from $9.7 \%$ to $2.8 \%$ as economy moves to low inflation regime. In the high inflation regime, the response of refined petroleum prices to oil shocks follows an increasing trend; starting with $33 \%$ in the first period and then reaching to $51 \%$ after twenty months. However refined petroleum products react in a different way in the low inflation regime; the response of this variable remains relatively stable, i.e. only \% 33 of changes in oil prices are passes through to refined prices, and persists only eleven months.

\section{CUMULATIVE RESPONSES TO ORTHOGONAL SHOCK TO DLRPET}

\section{FIGURE 3}

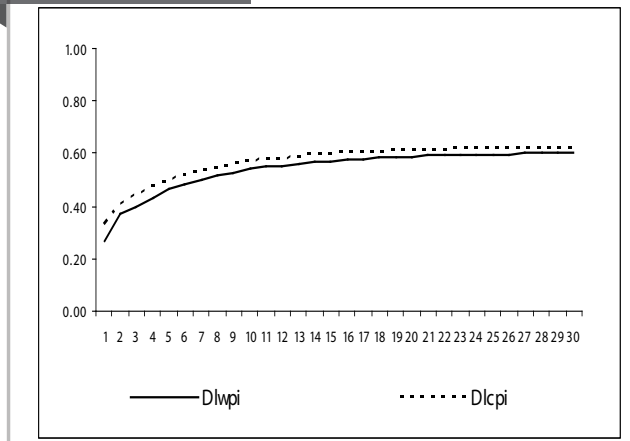

Regime 2 (High Inflation Regime)

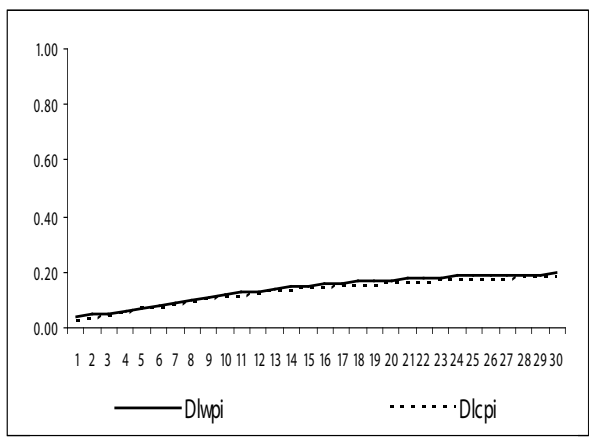

Regime 1 (Low Inflation Regime)

SOURCE: Author

Figure 3 shows that the responses of wholesale and consumer prices to the refined petroleum products prices have declined substantially in the low inflation regime. This evidence supports the proposition of Taylor (2000), low inflationary environment lowers the pass-through. In the high inflation regime $27.1 \%$ of changes in refined petroleum prices are passed-through to WPI in the first month, at the end of the period $60.2 \%$ of changes are reflected. However in the low inflation regime pass-through to that variable is limited with $19.4 \%$ and it is completed within 24 months. Responses of consumer prices is slightly higher than that of wholesale prices in the high inflation regime with $62.4 \%$, however as economy moves to low inflation regime it becomes lower with $17.9 \%$ even than the responses of wholesale prices. 
CUMULATIVE RESPONSES TO ORTHOGONAL SHOCK TO Dler $_{t}$

\section{FIGURE 4}

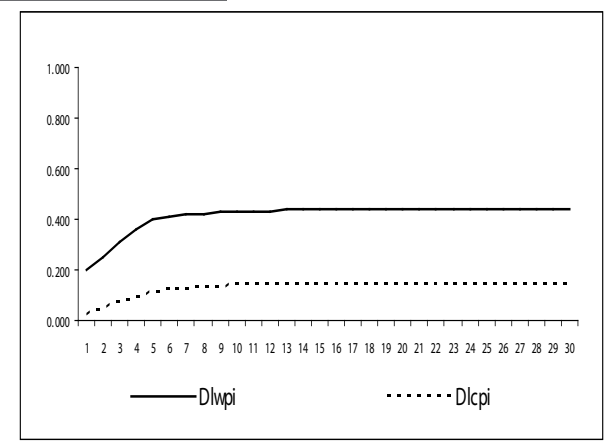

Regime 2 (High Inflation Regime)

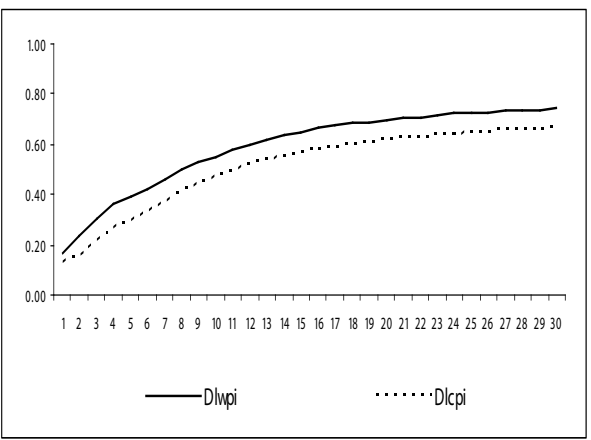

Regime 1 (Low Inflation Regime)

SOURCE: Author

Figures 4 and 5 provide some evidence on the intuition behind the decline in pass-through from refined petroleum prices in the low inflation regime. In the high inflation regime exchange rate pass-through to wholesale and consumer prices are $74.3 \%$ and $66.4 \%$. However the respective figures are obtained as $43.9 \%$ and $14.4 \%$ in the low inflation regime. This decline can be attributed to change in the monetary policy regime. The implementation of inflation targeting strategy with floating exchange rate regime can be seen as a potential reason behind the decline in the oil pass-through.

\section{CUMULATIVE RESPONSE OF DLCPI TO $D L N W P I_{T}$}

\section{FIGURE 5}

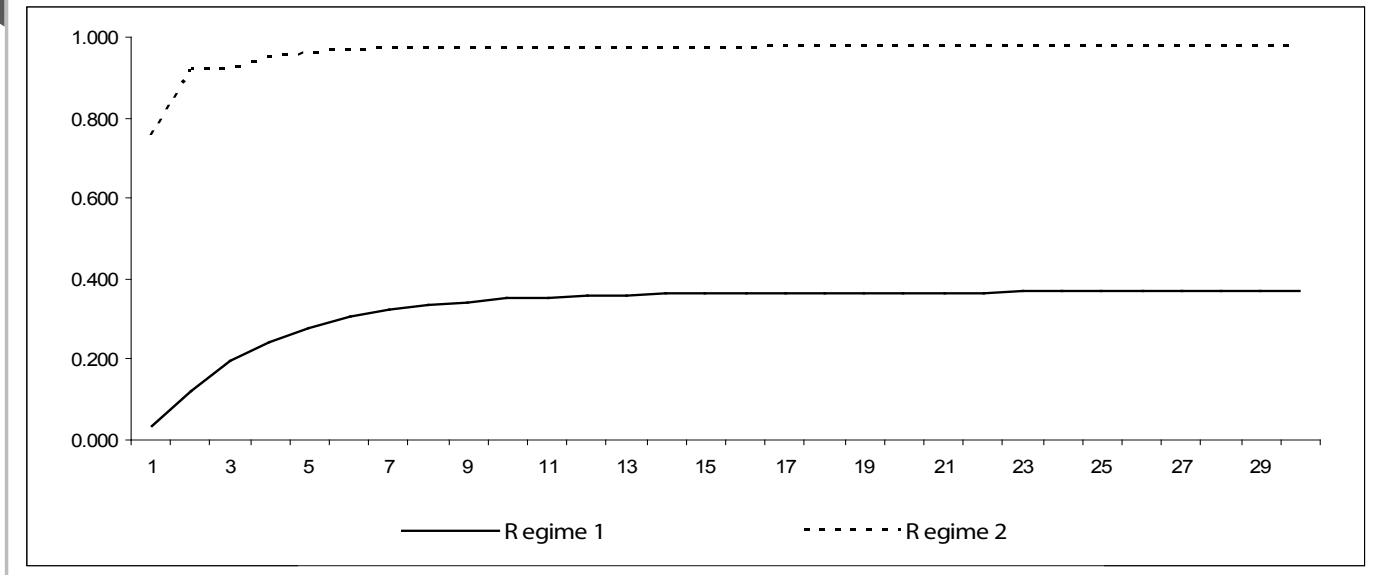

SOURCE: Author 
Figure 5 shows that decline in pass-through from refined petroleum prices to inflation variables can be also adhered to weakening the relationship between consumer and wholesale prices. Cumulative responses of consumer prices to wholesale prices were very fast, i.e. $71.5 \%$ of the changes are reflected within four months. However the response of consumer prices decreased to $36.7 \%$ as economy moves to the low inflation regime.

In addition to the responses to shocks in the variables, regime-dependent responses also allow us to analyze the responses of variables to the transition from high to low inflation regimes. ${ }^{11}$ The responses of prices and exchange rates to regime changes plotted in Figure 6 are in line with general findings of cumulative responses. Figure 6 shows that low inflation regime tends to be associated with exchange rate appreciation and the decline in the refined petroleum prices. The reverse type of this movement can be seen in the case of high inflation regime. The responses of variables to regime 2 are found to be considerably larger than those of regime 1, providing further support for the proposition of Taylor (2000). The responses of variables to regime changes follow similar patterns, except crude oil price changes. It is also remarkable that wholesale and consumer prices have identical regime shift responses in each regime.

\section{RESPONSES TO REGIME SHIFTS}

\section{FIGURE 6}
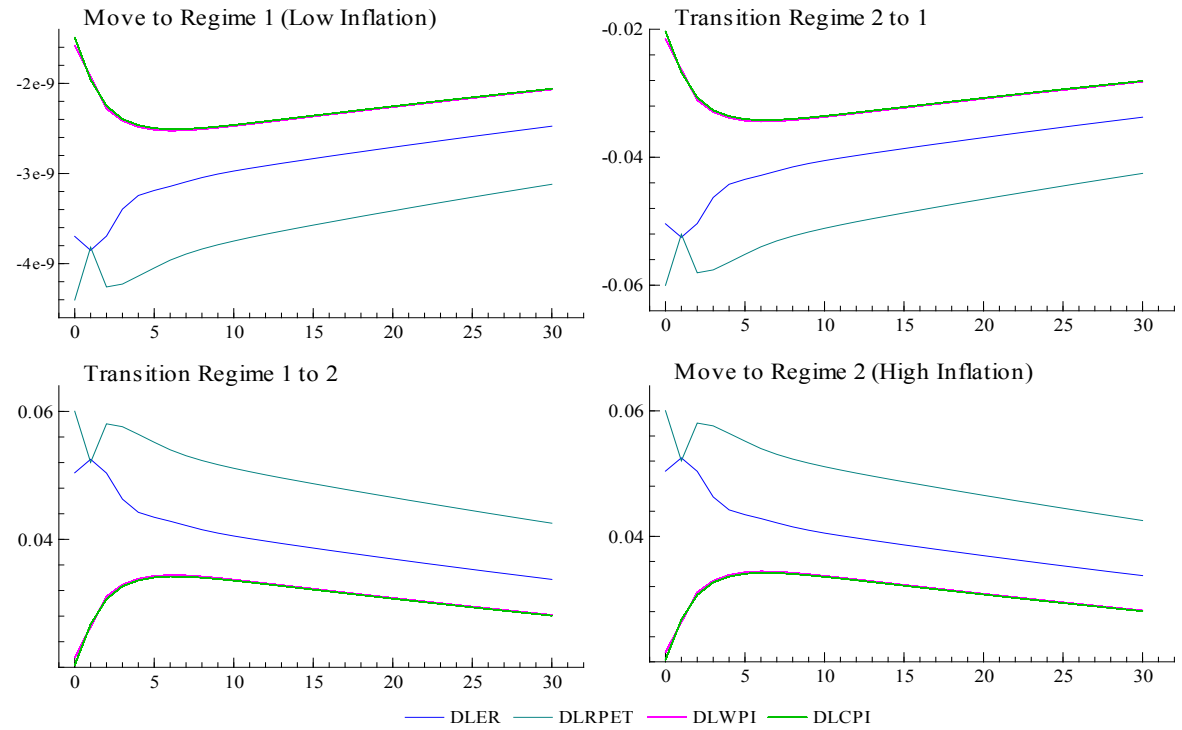

SOURCE: Author

\footnotetext{
${ }^{11}$ See Krolzig and Toro (1998) for the mathematical details on the derivation of regime shift responses.
} 


\section{CONCLUSION}

This paper analyses the existence of oil pass through to inflation under different inflation regimes in Turkey. In order to consider the impacts of non-linearity and structural breaks regime-dependent impulse response analysis based on MS-VAR model is employed.

Our estimates reveal the nonlinearity of the oil pass-through and indicate the existence of two different regimes characterized as the high and low inflation periods. We do not find strong direct pass through from imported oil prices to inflation in both regimes; this channel is working rather on refined petroleum product prices. This can be explained by the high taxes and exchange rate movements that break down the relationship between world and domestic prices in most of the oil importing developing countries.

Nonlinear regime-dependent impulse responses reveal the substantial decline in passthrough from refined petroleum prices to inflation as the economy moves from high to low inflation regime. In this respect, our analysis provides an empirical support for the proposition of Taylor (2000) low inflationary environment lowers the oil pass-through in Turkey.

Our results suggest that the decline in pass-through from refined petroleum prices in the low inflation regime can be largely attributed to the decline in the exchange rates. Therefore, for oil importing countries such as Turkey, policy makers should also consider exchange rate movements in the analysis of oil pass through. It is also interesting to note that the link between wholesale and consumer prices is weakened in the low inflation regime. The responses of consumer prices to wholesale prices are found to be very significant in the high inflation regime. However there is a substantial decrease when economy moves to low inflationary environment.

The results of this study point out that the extent of oil pass-through to domestic prices also is also determined by the overall macroeconomic environment. In this respect the achievement of price stability after the implementation of inflation targeting strategy seems to play a major role in the absorption of oil shocks in Turkey. Regime changes should be also taken into account by forecasting studies to provide more reliable predictions. In developing countries where taxes constitute a high portion of oil product prices, fiscal policy and monetary policy are linked closely. Our results imply that governments should endure the expectations on overall price stability before counting on tax revenues from oil products. 


\section{REFERENCES}

Akyürek, Cem. 2006. The Turkish crisis of 2001: a classic? Emerging Markets Finance and Trade 42: 5-32.

Aydoğuş, Osman. 1993. Türkiye ekonomisinde maliyet-fiyat ilişkileri, sektörel fiyat oluşumu ve enflasyon. 3. İzmir İktisat Kongresi, 4-7 June 1992, vol. 3: 35- 48, Sektörel Gelişme Stratejileri, Ankara: DPT.

Blanchard, Olivier J., and Jordi Gali. 2007. The macroeconomic effects of oil shocks: Why are the 2000s so different from the 197Os? NBER Working Paper Series, No. 13368.

Berument, Hakan, and Hakan Taşçı. 2002. Inflationary effect of crude oil prices in Turkey. Physica A: Statistical Mechanics and its Applications, 316, (1-4): 568-580.

Burbidge, John, and Alan Harrison. 1984. Testing for the effects of oil-price rises using vector autoregressions. International Economic Review, 25( 2): 459-484.

Chen, Shiu-Sheng. 2009. Oil price pass-through into inflation. Energy Economics, 31:126133.

Çatık, A. Nazif, and A. Özlem Önder. 2011. Inflationary effects of oil prices in Turkey: a regime-switching approach. Emerging Markets Finance and Trade, 5, September-October: 125-140.

Dempster, Arthur, P., Nan. M. Laird, and Rubin Donald. B. 1977. Maximum likelihood from incomplete data via the EM algorithm. Journal of the Royal Statistical Society, 39: 1-38.

Energy Market Regulatory Authority (EMRA). 2010. Oil market sectoral report: 2009. Energy market regulatory authority, web address: www.epdk.org.tr (30-06-2010).

Gisser, Micha, and Thomas H. Goodwin. 1986. Crude oil and the macroeconomy: tests of some popular notions. Journal of Money, Credit and Banking, 18 (1) : 95-103.

Hodrick, Robert J., and Edward C. Prescott. 1997. Postwar U.S. business cycles: An empirical investigation. Journal of Money, Credit, and Banking, 29: 1-16.

Hooker, Mark A. 2002. Are oil shocks inflationary? Asymmetric and nonlinear specifications versus changes in regime. Journal of Money, Credit and Banking, 34 (2): 540-61.

Kibritçioğlu, Aykut and Bengi Kibritçioğlu. 1999. Ham petrol ve akaryakıt ürünü fiyat artışlarının Türkiye'deki enflasyonist etkileri. Turkish Republic Undersecreteriat of Treasury, Working Paper Series, No. 21.

Krolzig, Hans Martin. 2006. Impulse-response analysis in markov switching vector autoregressive models. European Economic Association \& Econometric Society Congress, retrieved: http://www.keele.ac.uk/depts/ec/cer/esrc1/Krolzig.pdf, the date of access: June 15, 2010.

Krolzig, Hans Martin, and Juan Toro. 2001. A new approach to the analysis of business cycle transitions in a model of output and employment. University of Oxford, Department of Economics Working Paper Series, No. 9959.

LeBlanc, Michael, and Menzie D. Chinn. 2004. Do high oil prices presage inflation? Business Economics 39 (2): 38-48.

McCarthy, Jonathan. 1999. Pass-through of exchange rates and import prices to domestic inflation in some industrialized economies. BIS Working Paper No.79, Bank for International Settlements.

Önder, A. Özlem. 2009. The stability of the Turkish Phillips curve and alternative regime shifting models. Applied Economics, 41(20): 2597-2604.

Rabanal, Pau., and Gerd Schwartz. 2001. Exchange rate changes and consumer price inflation: 20 months after the floating of the real. IMF Country Report: Selected Issues and Statistical Appendix (Section V), Washington, DC: International Monetary Fund.

Taylor, John B. 2000. Low inflation, pass-through, and the pricing power of firms. 
European Economic Review, 44: 1389-1408.

Zivot, Eric, and Donald W.K. 1992. Further evidence on the Great Crash, the oil-price shock and the unit root hypothesis. Journal of Business and Economic Statistics, 10: 251270 . 


\section{Appendix}

\section{VARIABLES IN THE MS-VAR MODEL}

\section{FIGURE A1}
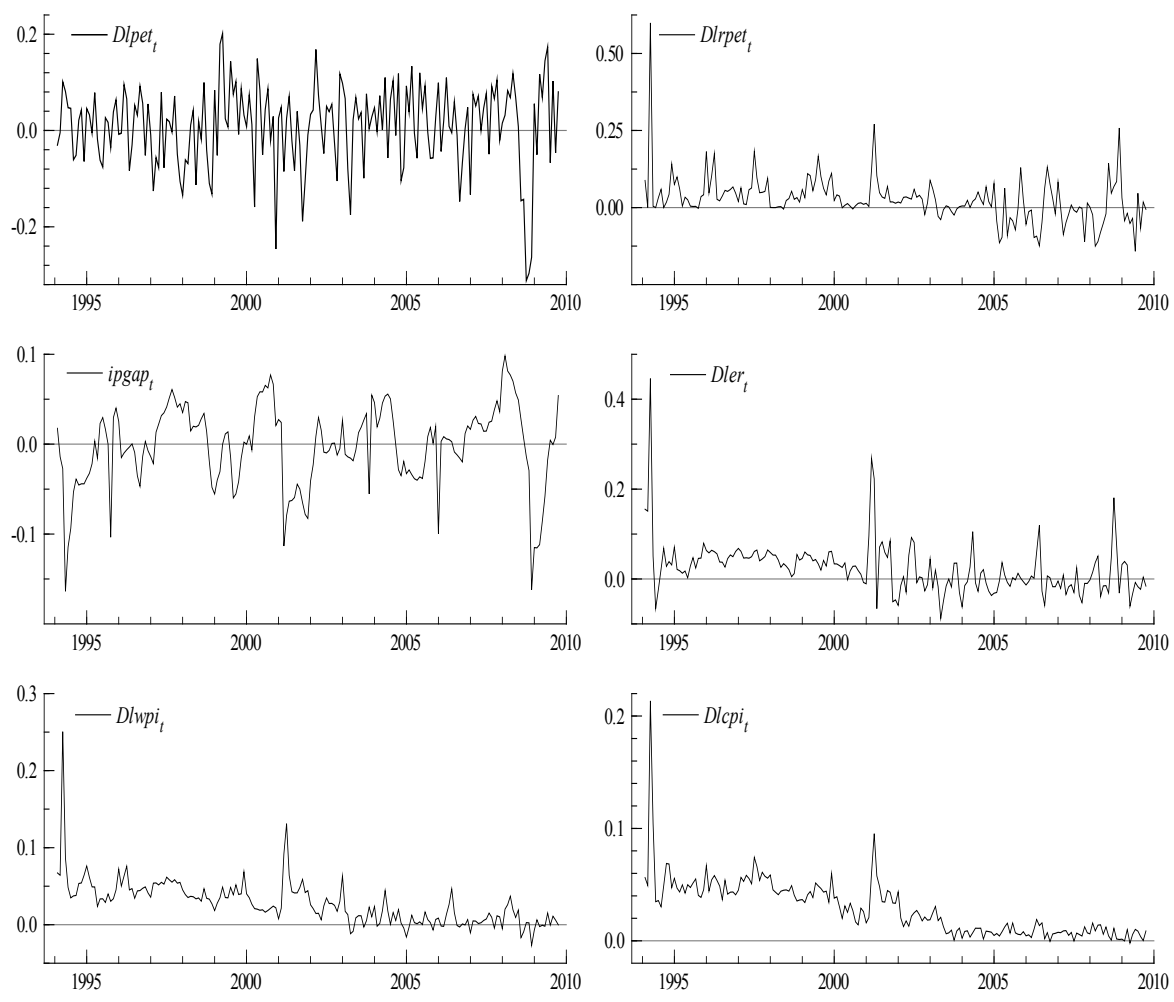

SOURCE: Author 
RESIDUAL ANALYSIS

\section{FIGURE A2}
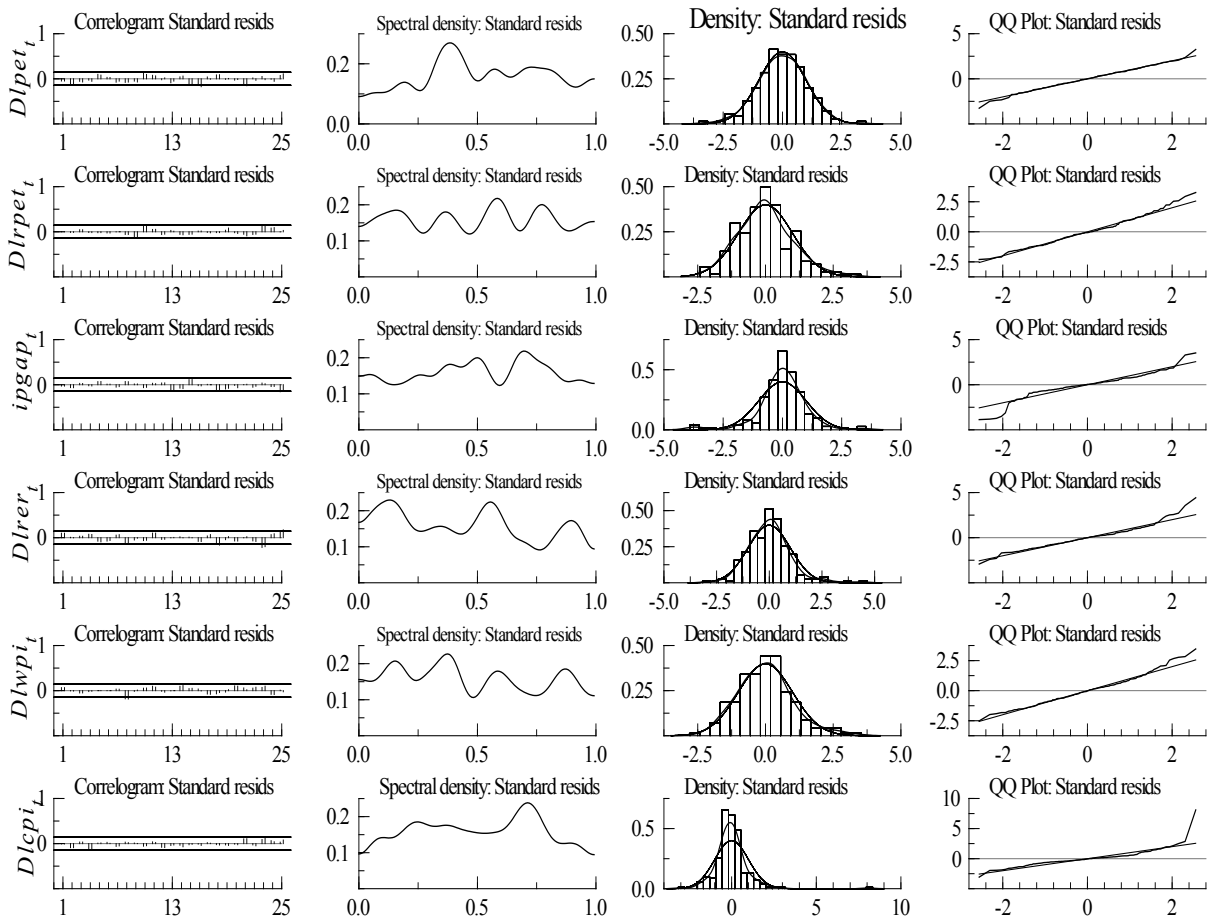

SOURCE: Author 
Table A1. Maximum Likelihood Estimation of MS-VAR model

\begin{tabular}{|c|c|c|c|c|c|c|}
\hline 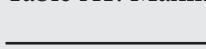 & Dlpet $_{t}$ & Dlrpet $_{t}$ & $i p g a p_{t}$ & Dlne $_{t}$ & $D \ln w p i_{t}$ & $D \ln c p i_{t}$ \\
\hline \multirow[t]{2}{*}{ Const(Reg.1) } & 0.013 & -0.002 & 0.000 & 0.003 & 0.003 & 0.003 \\
\hline & $(1.232)$ & $(-0.304)$ & $(0.124)$ & $(0.620)$ & $(2.143)$ & $(4.372)$ \\
\hline \multirow[t]{2}{*}{ Const(Reg.2) } & 0.020 & 0.037 & 0.009 & 0.046 & 0.017 & 0.018 \\
\hline & $(1.819)$ & $(2.504)$ & $1.202)$ & $(3.865)$ & $(3.611)$ & $(4.824)$ \\
\hline \multirow[t]{2}{*}{$D \operatorname{lnpet} t_{t-1}$} & 0.073 & 0.033 & 0.004 & -0.004 & 0.012 & 0.007 \\
\hline & $(2.02)$ & $(1.506)$ & $(0.151)$ & $(-0.105)$ & $(1.024)$ & $(0.852)$ \\
\hline \multirow[t]{2}{*}{$D \operatorname{lnpet} t_{t-2}$} & 0.061 & 0.022 & 0.031 & 0.005 & -0.012 & 0.006 \\
\hline & $(2.34)$ & (2.094) & $(1.218)$ & $(0.131)$ & $(-1.152)$ & $(0.788)$ \\
\hline \multirow[t]{2}{*}{ Dlrpet $_{t-1}$} & 0.071 & 0.256 & -0.024 & 0.034 & 0.002 & 0.003 \\
\hline & $(0.675)$ & $(3.977)$ & $(-0.631)$ & $(0.680)$ & $(0.102)$ & $(0.273)$ \\
\hline \multirow[t]{2}{*}{ Dlrpet $_{t-2}$} & -0.151 & 0.015 & -0.062 & 0.105 & 0.008 & 0.001 \\
\hline & $(-1.512)$ & $(0.251)$ & $(-1.686)$ & $(2.162)$ & $(1.720)$ & (1.739) \\
\hline \multirow[t]{2}{*}{$\operatorname{ipgap}_{t-1}$} & -0.101 & -0.124 & 0.619 & -0.053 & -0.016 & -0.002 \\
\hline & $(-0.517)$ & $(-1.107)$ & $(8.272)$ & $(-0.544)$ & $(-0.571)$ & $(-0.124)$ \\
\hline \multirow[t]{2}{*}{ ipgap $_{t-2}$} & -0.159 & 0.096 & 0.116 & 0.173 & 0.015 & 0.008 \\
\hline & $(-0.883)$ & $(0.935)$ & $(1.692)$ & (1.917) & $(0.571)$ & $(0.505)$ \\
\hline \multirow[t]{2}{*}{$\operatorname{Dlne}_{t-1}$} & -0.314 & 0.030 & -0.080 & 0.454 & 0.101 & 0.016 \\
\hline & $(-1.801)$ & $(0.304)$ & $(-1.247)$ & $(5.221)$ & $(3.921)$ & $(2.423)$ \\
\hline \multirow[t]{2}{*}{$D \ln e_{t-2}$} & 0.324 & 0.032 & -0.069 & -0.200 & -0.051 & 0.029 \\
\hline & $(2.066)$ & $(0.349)$ & $(-1.175)$ & $(-2.468)$ & $(-2.080)$ & $(1.686)$ \\
\hline \multirow[t]{2}{*}{$D \ln w p i_{t-1}$} & 0.290 & 0.270 & -0.058 & -0.053 & 0.285 & 0.115 \\
\hline & $(0.580)$ & $(0.940)$ & $(-0.319)$ & $(-0.208)$ & $(3.640)$ & $(2.128)$ \\
\hline \multirow[t]{2}{*}{$D \ln w p i_{t-2}$} & 0.042 & 0.146 & 0.323 & -0.018 & 0.195 & 0.075 \\
\hline & $(0.089)$ & $(0.529)$ & $(1.849)$ & $(-0.073)$ & $(2.616)$ & $(1.441)$ \\
\hline \multirow[t]{2}{*}{$D \operatorname{lncpi} i_{t-1}$} & -0.155 & -0.163 & -0.312 & -0.901 & -0.197 & 0.265 \\
\hline & $(-0.246)$ & $(-1.047)$ & $(-1.339)$ & $(-2.717)$ & $(-1.830)$ & $(3.425)$ \\
\hline \multirow[t]{2}{*}{$D \operatorname{lncpi} i_{t-2}$} & -0.441 & 0.681 & 0.048 & 0.549 & 0.248 & 0.159 \\
\hline & $(-0.692)$ & $(1.764)$ & $(0.205$ & $(1.645)$ & $(2.212)$ & $(1.968)$ \\
\hline Std. Err. (Regime 1) & 0.089 & 0.061 & 0.027 & 0.034 & 0.013 & 0.005 \\
\hline Std. Err. (Regime 2) & 0.077 & 0.071 & 0.027 & 0.054 & 0.024 & 0.020 \\
\hline
\end{tabular}

Note: $t$-statistics of the parameters are given in parentheses. 


\section{PRIJENOS CIJENE NAFTE NA DOMAĆE CIJENE U TURSKOJ: JESU LI PROMJENE U REŽIMU INFLACIJE BITNE?}

\section{SAŽETAK}

Ovaj rad istražuje postojanje prijenosa cijene nafte na inflaciju pri različitim režimima inflacije u Turskoj. Kako bi se usporedila razlika između efekata prijenosa cijene nafte na periode niske i visoke inflacije, koristili smo se vektorskim autoregresijskim modelom Markovljeve promjene režima (MS-VAR) kao nelinearnim okvirom procjene. Odzivi na impulse ovisni o režimu ne ukazuju na snažan prijenos cijena sirove nafte na inflaciju u oba režima. Ipak, taj kanal funkcionira sa cijenama rafiniranih naftnih proizvoda. Rezultati pokazuju da postoji konkretni pad u prijenosu cijena rafiniranih naftnih proizvoda na inflaciju kako se ekonomija premješta s visokog na režim niske inflacije. Ti rezultati podupiru Taylorovu hipotezu (2000) koja sugerira da okolina niske inflacije vodi ka niskom prijenosu.

Ključne riječi: inflacija, naftni šokovi, prijenos, odzivi na impulse ovisni o režimu, MS-VAR modeli. 
Economic Research - Ekonomska istraživanja, Vol. 25 (2012) No. 2 (277-296) 